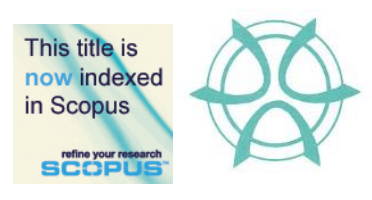

PLANNING MALAYSIA:

Journal of the Malaysian Institute of Planners

VOLUME 17 ISSUE 2 (2019), Page 280 - 289

\title{
EMPOWERING COMMUNITY MOVEMENT: EMPRICAL EVIDENCE
}

\author{
Aisyah Abu Bakar', Mariana Mohamed Osman² \& Muhammad Faris Abdullah ${ }^{3}$ \\ ${ }^{1,2}$ Kulliyyah of Architecture and Environmental Design, \\ INTERNATIONAL ISLAMIC UNIVERSITY MALAYSIA
}

\begin{abstract}
The living environment in which humans dwell in and are surrounded by, and thus include the immediate built environment, is fertile ground for personal development leading to community advancement. Issue: Ample amount of studies have been carried out on the influence of personal empowerment (PE) on community movement $(\mathrm{CM})$. Little attention was given to the empirical evidence of the impact of PE on CM. Purpose: This paper sets out to confirm the statistical predictability of CM based on PE. Approach: Multiple Correlation and Multiple Linear Regression were executed to assess linear associations and parameters of linear equations to predict CM components based on PE items. Findings: Majority of PE items were significant predictors of CM components and 'setting goals and striving to meet goals' was the strongest predictor of CM.
\end{abstract}

Keywords: community movement, personal empowerment 
PLANNING MALAYSIA

Journal of the Malaysia Institute of Planners (2019)

\section{INTRODUCTION}

Interdependency between human and other humans $(\mathrm{HIH})$ is a significant causal agent of subjective sustainable well-being (SSWB). Understanding HIH helps architects plan and design houses, cities and other kinds of human habitations to enhance individual empowerment resulting to improved community development. Awareness deficits on HIH and SSWB can lead to users' dissatisfaction, alienation and eventually weak community interaction. Personal empowerment (PE) and community movement (CM) are dimensions of $\mathrm{HIH}$. Many authors have theoretically recognised the positive impact of PE on CM. This paper measures the statistical predictability of CM based on PE.

\section{LITERATURE REVIEW}

Case studies based on articles from selected Asian Journals from the year 2011 onwards highlight conditional factors and potential determinants of Community Movement (CM). Table 1 summarises these findings.

Table 1 Conditional factors and potential determinants for community movement

\begin{tabular}{|c|c|c|}
\hline Conditional Factors & Potential Determinants & References \\
\hline $\begin{array}{l}\text { Sensory overload (over-stimulation from the } \\
\text { environment due to overcrowding - how long the } \\
\text { neighbourhood has been established, the diversity } \\
\text { composition of its people and the surrounding } \\
\text { developments), and the degree of cohesion }\end{array}$ & $\begin{array}{l}\text { collective actions (taking actions } \\
\text { together for a common objective), } \\
\text { inclusion (embracing), trust, and } \\
\text { belongingness }\end{array}$ & $\begin{array}{l}\text { Hamdan, } \\
\text { Yusof, \& } \\
\text { Marzukhi } \\
(2014)\end{array}$ \\
\hline $\begin{array}{l}\text { Social capital, participation, awareness, concern and } \\
\text { care for each other, inter-racial relationships, sense of } \\
\text { belongingness, a sense of trust and approach on shared } \\
\text { life values and shared social obligations. }\end{array}$ & $\begin{array}{l}\text { proactivity, tolerance, a sense of } \\
\text { trust and protection (the feeling of } \\
\text { safe and assured), and shared values }\end{array}$ & $\begin{array}{l}\text { Ahmad } \\
\text { Marzuki et al. } \\
\quad(2014)\end{array}$ \\
\hline $\begin{array}{l}\text { p defined as } \\
\text { nds, family } \\
\text { when needed }\end{array}$ & $\begin{array}{l}\text { seness } \\
\text { id }\end{array}$ & $\begin{array}{r}\text { Ibr } \\
\text { Ham }\end{array}$ \\
\hline $\begin{array}{l}\text { Sense of integration (incorporation of community } \\
\text { members), safety and trust among neighbours, trust } \\
\text { among people in general, trust among members in } \\
\text { formal groups, openness to communicate and discuss } \\
\text { any issues concerning the community }\end{array}$ & $\begin{array}{l}\text { lent (collective } \\
\text { lve issues of public } \\
\text { areness (concern on } \\
\text { al issues), trust and }\end{array}$ & $\begin{array}{l}\text { Chon } \\
\text { Er, \& } \\
\quad(20\end{array}$ \\
\hline $\begin{array}{l}\text { arded as more } \\
\text { action) and } \\
\text { quirements) }\end{array}$ & o & $\begin{array}{l}\text { Mah } \\
\text { Sino }\end{array}$ \\
\hline $\begin{array}{l}\text { ities), trust } \\
\text { network } \\
\text { of help). }\end{array}$ & $\begin{array}{l}\text { of one's own } \\
\text { hings), trust, and }\end{array}$ & Nav \\
\hline $\begin{array}{l}\text { Willingness to celebrate diversity: appreciate each } \\
\text { other's contribution, helping others in needs. Ethnic } \\
\text { composition and geographical population - the lesser } \\
\text { diversity, the higher willingness to tolerate others. }\end{array}$ & $\begin{array}{l}\text { Tolerance to diversity (to accept } \\
\text { something foreign to one's own } \\
\text { through openness, appreciation, } \\
\text { helpfulness and respect of others) }\end{array}$ & $\begin{array}{l}\text { Yassin et al. } \\
\quad(2013)\end{array}$ \\
\hline $\begin{array}{l}\text { Racial microaggression (indirect and subtle form of } \\
\text { racism in everyday life intentionally and unintentionally } \\
\text { executed by the perpetrators and often catch the } \\
\text { recipients off-guard) }\end{array}$ & $\begin{array}{l}\text { tions upon } \\
\text { qual and } \\
\text { s) }\end{array}$ & $\begin{array}{r}\text { Lino, } \mathrm{H} \\
\& \mathrm{Ri} \\
(20\end{array}$ \\
\hline (umpleasant emotion & respect, open mindedness & Rahyla (2017) \\
\hline
\end{tabular}


Aisyah Abu Bakar, Mariana Mohamed Osman \& Muhammad Faris Abdullah Empowering Community Movement: Empirical Evidence

\begin{tabular}{|c|c|c|}
\hline $\begin{array}{l}\text { Meaningful activities (activities that have important } \\
\text { purposes, useful qualities, and consequential) }\end{array}$ & $\begin{array}{l}\text { Volunteering (freely offering to } \\
\text { undertake tasks), }\end{array}$ & $\begin{array}{l}\text { Tunku, } \\
\text { Rahman, \& } \\
\text { Campus } \\
(2017) \\
\end{array}$ \\
\hline $\begin{array}{l}\text { Attitudinal factors (instrumental values, desirability of } \\
\text { volunteering, attitude and satisfaction from } \\
\text { volunteering) and motivational factors (altruism, } \\
\text { egoism, religiosity, social obligation, political interest) }\end{array}$ & $\begin{array}{l}\text { Volunteer commitment (keenness to } \\
\text { offer assistance), and solidarity } \\
\text { (mutual support within a group) }\end{array}$ & $\begin{array}{c}\text { Thomas, } \\
\text { Selvadurai, } \\
\text { Er, Lyndon, \& } \\
\text { Moorthy } \\
\text { (2011) }\end{array}$ \\
\hline $\begin{array}{l}\text { Gender - female score higher in Islamic religiosity } \\
\text { (striving, universality, integrity, respect, surrendering, } \\
\text { trust, humility, and practical spiritual consciousness). }\end{array}$ & $\begin{array}{l}\text { Tolerance, moderation (restraining } \\
\text { self from something extreme) }\end{array}$ & $\begin{array}{c}\text { Ortega \& } \\
\text { Krauss (2013) }\end{array}$ \\
\hline
\end{tabular}

The findings from the case studies generate three significant components of CM: (i) Proactive Participation (CMa), (ii) Affability and Respect for Diversity $(\mathrm{CMb})$ and (iii) Belongingness $(\mathrm{CMc})$.

Table 2 Components and determinants of community movement

\begin{tabular}{|c|c|c|c|}
\hline Definition of CM & Components & Indicators & Code \\
\hline \multirow{10}{*}{$\begin{array}{l}\text { Sense of } \\
\text { inclusiveness } \\
\text { expressed in open } \\
\text { and friendly } \\
\text { interaction, } \\
\text { awareness and } \\
\text { helpfulness in the } \\
\text { social network and } \\
\text { initiatives to be } \\
\text { more engaged }\end{array}$} & \multirow{3}{*}{$\begin{array}{c}\text { Proactive } \\
\text { Participation }\end{array}$} & conscious of new updates & \multirow{3}{*}{$\mathrm{CMa}$} \\
\hline & & participating enthusiastically in organized activities & \\
\hline & & assuming responsibility when foreseeing community issues & \\
\hline & \multirow{4}{*}{$\begin{array}{c}\text { Affability } \\
\text { and Respect } \\
\text { for Diversity }\end{array}$} & approachable to people of different ethnicity and religion & \multirow{4}{*}{$\mathrm{CMb}$} \\
\hline & & approachable to people of different ranks and status & \\
\hline & & enjoying social interaction with community & \\
\hline & & adapting and adjusting fast to new social environment & \\
\hline & \multirow{3}{*}{$\begin{array}{c}\text { Belonging- } \\
\text { ness }\end{array}$} & ability to influence shared decisions & \multirow{3}{*}{$\mathrm{CMc}$} \\
\hline & & offering assistance voluntarily when necessary & \\
\hline & & feeling sense of belonging with the community & \\
\hline
\end{tabular}

Personal Empowerment (PE) manifests in the opportunity to exercise control, voice and choice with regards to social surroundings. Qualities adhere to PE include (i) self-motivation with regards to goal orientation, autonomy and self-regulation (Chin, Khoo, \& Low, 2012; Kok, 2016), (ii) social acceptance and coherence with others (Nesbit, Jepsen, Demirian, \& Ho, 2012; Kadir, Omar, Desa, \& Yusooff, 2013; Zamani, Khairudin, Sulaiman, Halim, \& Nasir, 2013), and (iii) composure, stability and resilience (Sulaiman et al., 2013; Sipon, Nasrah, Nazli, Abdullah, \& Othman, 2014).

Table 3 Determinants of personal empowerment

\begin{tabular}{lll}
\hline \multicolumn{1}{c}{ Definition of PE } & Indicators & Code \\
\hline & \multicolumn{1}{l}{ setting goals and striving to meet goals } & PE1 \\
\cline { 2 - 3 } & striving and working hard even for easy goals & PE2 \\
\cline { 2 - 3 } $\begin{array}{l}\text { Self-esteem in taking control over } \\
\text { life along with sense of composure } \\
\text { to progress in the social } \\
\text { environment }\end{array}$ & monitoring behaviours to suit with situations & PE3 \\
\cline { 2 - 3 } & knowing when somebody is offended & PE4 \\
\cline { 2 - 3 } & ensuring others are comfortable when making deals & PE5 \\
\cline { 2 - 3 } & able to be friendly with distasteful persons when necessary & PE6 \\
\cline { 2 - 3 } & able to work out solutions during stress and difficulties & PE7 \\
\cline { 2 - 3 } & tackling problems efficiently in unexpected conditions & PE8 \\
\cline { 2 - 3 } & feeling energetic for daily routines and activities & PE9 \\
\cline { 2 - 3 } & having hardly distracted and focus mind & PE10 \\
\hline
\end{tabular}


PLANNING MALAYSIA

Journal of the Malaysia Institute of Planners (2019)

Based on theoretical underpinnings, this research hypothesises that $\mathrm{CM}$ components are predictable by $\mathrm{PE}$. The following sections provide empirical evidence to the predictability of $\mathrm{CMa}, \mathrm{CMb}$ and $\mathrm{CMc}$ based on $\mathrm{PE}$ items.

\section{METHOD}

A sample of 4,315 was gathered after the data screening process. The Malaysian respondents were given an 11-point Likert scale to respond to questionnaire items which include the components of CM and the ten (10) PE items. Pearson correlation analyses were conducted to observe if there were linear associations between the CM components and PE items. Ensuing correlation analyses, multiple linear regression analyses were conducted to estimate parameters of the linear equations used to predict values of $\mathrm{CMa}, \mathrm{CMb}$ and $\mathrm{CMc}$ from $\mathrm{PE}$ items.

\section{RESULTS AND DISCUSSION}

At $95 \%$ confidence level, there were statistically significant positive correlations between (i) CMa and each of PE items, (ii) $\mathrm{CMb}$ and each of PE items, and (iii) $\mathrm{CMc}$ and each of PE items. The null hypotheses claiming there are no statistically significant correlations between (i) $\mathrm{CMa}$ and respective $\mathrm{PE}$ items, (ii) $\mathrm{CMb}$ and respective $\mathrm{PE}$ items, and (iii) $\mathrm{CMc}$ and respective $\mathrm{PE}$ items were all rejected.

Table 4 Multiple Correlations between PE items and $\mathrm{CMa}, \mathrm{CMb}$ and $\mathrm{CMc}$

\begin{tabular}{|c|c|c|c|c|c|c|c|c|c|c|c|}
\hline \multicolumn{12}{|c|}{$\mathrm{H}_{0}$ There is no statistically significant correlation between CMa and respective PE items } \\
\hline \multicolumn{12}{|c|}{$\mathrm{H}_{0} \mathrm{~T}$} \\
\hline \multicolumn{12}{|c|}{$\mathrm{H}_{0}$} \\
\hline \multicolumn{12}{|c|}{ Correlation Strength Threshold (Dancey \& Reidy, 2004) } \\
\hline 0 & .1 & .2 & .3 & & 4 & & .6 & .7 & .8 & .9 & 1 \\
\hline zero & \multicolumn{3}{|c|}{ weak } & \multicolumn{4}{|c|}{ moderate } & \multicolumn{3}{|c|}{ strong } & perfect \\
\hline DV & Stats & PE1 & PE2 & PE3 & PE4 & PE5 & PE6 & PE7 & PE8 & PE9 & PE10 \\
\hline \multirow{3}{*}{ CMa } & $\mathrm{r}$ & $.385^{* *}$ & $.384^{* *}$ & $.362^{* * *}$ & $.352^{* *}$ & $.343^{* *}$ & $.353^{\text {** }}$ & $.347^{* *}$ & $.340^{* *}$ & $.352^{* * *}$ & $.322^{* * *}$ \\
\hline & $p$ & .000 & .000 & .000 & .000 & .000 & .000 & .000 & .000 & .000 & .000 \\
\hline & $\mathrm{N}$ & 4315 & 4315 & 4315 & 4315 & 4315 & 4315 & 4315 & 4315 & 4315 & 4315 \\
\hline \multirow{3}{*}{$\mathrm{CMb}$} & $\mathrm{r}$ & $.416^{* *}$ & $.420^{* * *}$ & $.415^{* *}$ & $.367^{* *}$ & $.404^{* * *}$ & $.352^{* * *}$ & $.371^{* *}$ & $.351^{* *}$ & $.372^{* * *}$ & $.331^{* *}$ \\
\hline & $p$ & .000 & .000 & .000 & .000 & .000 & .000 & .000 & .000 & .000 & .000 \\
\hline & $\mathrm{N}$ & 4315 & 4315 & 4315 & 4315 & 4315 & 4315 & 4315 & 4315 & 4315 & 4315 \\
\hline \multirow{3}{*}{$\mathrm{CMc}$} & $\mathrm{r}$ & $.420^{* *}$ & $.430^{* *}$ & $.421^{* *}$ & $.390^{* * *}$ & $.419^{* *}$ & $.362^{* * *}$ & $.383^{* *}$ & $.373^{* *}$ & $.397^{* * *}$ & $.358^{* * *}$ \\
\hline & $\mathrm{p}$ & .000 & .000 & .000 & .000 & .000 & .000 & .000 & .000 & .000 & .000 \\
\hline & $\mathrm{N}$ & 4315 & 4315 & 4315 & 4315 & 4315 & 4315 & 4315 & 4315 & 4315 & 4315 \\
\hline
\end{tabular}

Statistical Interpretation of Multiple Correlation Analyses

At $95 \%$ confidence level, there were statistically significant and moderate correlations between $\mathrm{CMa}$

$\mathrm{CMa}$ and (i) PE1 ( $\mathrm{r}=.385, \mathrm{p}=.000)$; (ii) PE2 ( $\mathrm{r}=.384, \mathrm{p}=.000)$; (iii) PE3 ( $\mathrm{r}=.362, \mathrm{p}=.000$ ); (iv) PE4 ( $\mathrm{r}$ $=.352, \mathrm{p}=.000) ;(\mathrm{v})$ PE5 ( $\mathrm{r}=.343, \mathrm{p}=.000) ;(\mathrm{vi})$ PE6 ( $\mathrm{r}=.353, \mathrm{p}=.000) ;($ vii) PE7 ( $\mathrm{r}=.347, \mathrm{p}=.000)$; (viii) PE8 ( $\mathrm{r}=.340, \mathrm{p}=.000)$; (ix) PE9 ( $\mathrm{r}=.352, \mathrm{p}=.000)$; (x) PE10 ( $\mathrm{r}=.322, \mathrm{p}=.000)$.

At $95 \%$ confidence level, there were statistically significant and moderate correlations between $\mathrm{CMb}$

$\mathrm{CMb}$ and (i) PE1 ( $\mathrm{r}=.416, \mathrm{p}=.000)$; (ii) PE2 ( $\mathrm{r}=.420, \mathrm{p}=.000)$; (iii) PE3 ( $\mathrm{r}=.415, \mathrm{p}=.000$ ); (iv) PE5 ( $\mathrm{r}$ $=.404, \mathrm{p}=.000)$. Additionally, there were statistically significant and weak correlations between 
Aisyah Abu Bakar, Mariana Mohamed Osman \& Muhammad Faris Abdullah Empowering Community Movement: Empirical Evidence

CMb and (v) PE4 ( $r=.367, p=.000)$; (vi) PE6 ( $r=.352, p=.000) ;$ (vii) PE7 ( $r=.371, p=.000)$; (viii) PE8 ( $\mathrm{r}=.351, \mathrm{p}=.000)$; (ix) PE9 $(\mathrm{r}=.372, \mathrm{p}=.000) ;(\mathrm{x})$ PE10 $(\mathrm{r}=.331, \mathrm{p}=.000)$.

At $95 \%$ confidence level, there were statistically significant and moderate correlations between CMc and (i) PE1 ( $\mathrm{r}=.420, \mathrm{p}=.000)$; (ii) PE2 ( $\mathrm{r}=.430, \mathrm{p}=.000)$; (iii) PE3 ( $\mathrm{r}=.421, \mathrm{p}=.000)$; (iv) PE5 ( $\mathrm{r}$

$\mathrm{CMc}=.419, \mathrm{p}=.000)$. Additionally, there were statistically significant and weak correlations between CMc and (v) PE4 ( $\mathrm{r}=.390, \mathrm{p}=.000)$; (vi) PE6 ( $\mathrm{r}=.362, \mathrm{p}=.000)$; (vii) PE7 ( $\mathrm{r}=.383, \mathrm{p}=.000$ ); (viii) PE8 ( $\mathrm{r}=.373, \mathrm{p}=.000)$; (ix) PE9 ( $\mathrm{r}=.397, \mathrm{p}=.000)$; $(\mathrm{x})$ PE10 $(\mathrm{r}=.358, \mathrm{p}=.000)$.

Three (3) multiple regression analyses were carried out to predict the values of each of dependent variables (i) $\mathrm{CMa}$, (ii) $\mathrm{CMb}$ and (iii) $\mathrm{CMc}$ given the set of PE explanatory variables (PE1, PE2, PE3, PE4, PE5, PE6, PE7, PE8, PE9, and PE10).

Table 5 Multiple Linear Regression - PE predicting CMa

$\mathrm{H}_{0}$ There will be no significant prediction of CMa by PE1, PE2, PE3, PE4, PE5, PE6, PE7, PE8, PE9 and PE10

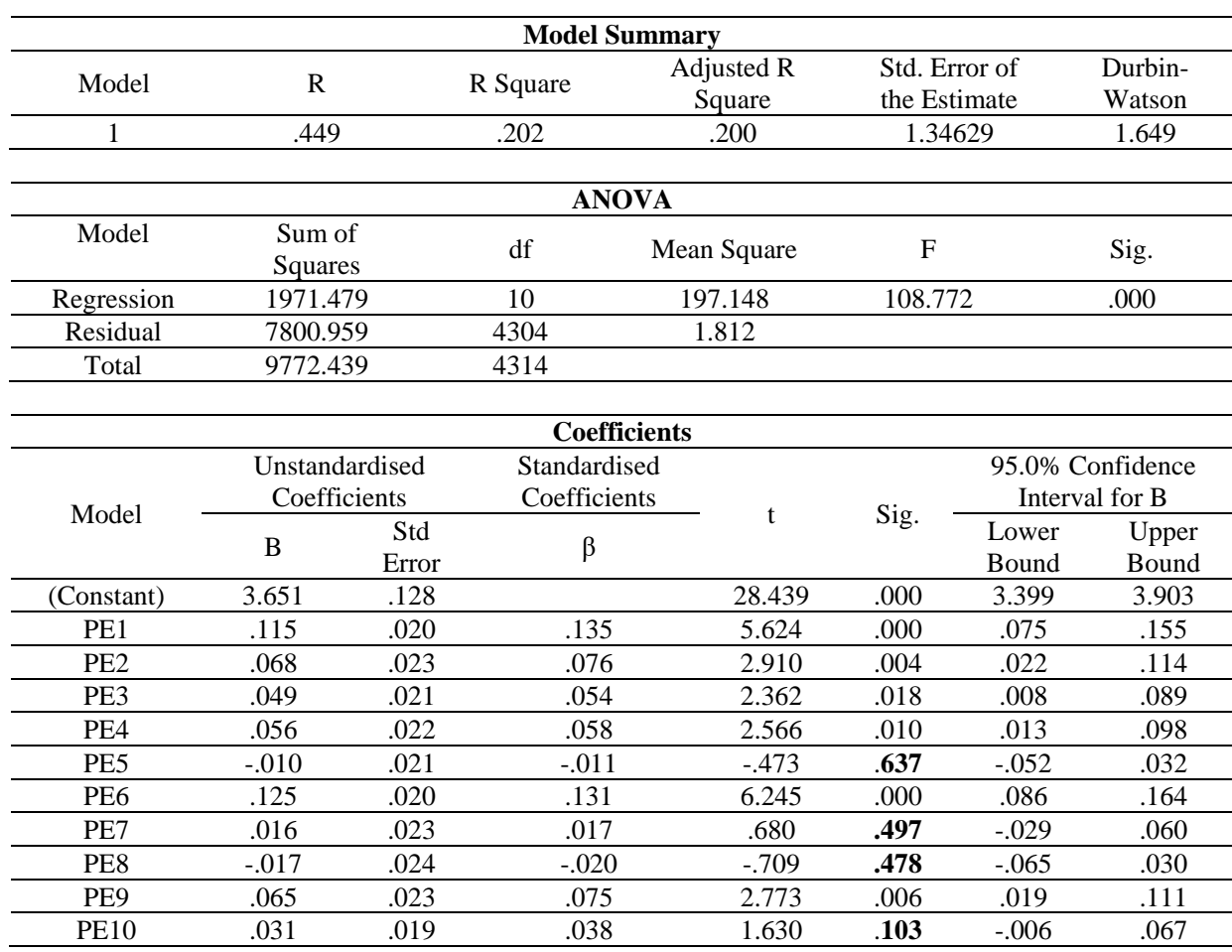

A multiple regression was generated to predict CMa based on PE items. $R$ value of .449 indicated a satisfactory level of prediction $(R>0.4)$. The DurbinWatson statistic was 1.649 which is between 1.5 and 2.5 and therefore the data was not autocorrelated. A significant regression equation was found, $F(10,4304)$ 
$=108.772, \mathrm{p}=.000$, with an $\mathrm{R}^{2}$ of .202 ; indicating that the proportion of variance in CMa that can be explained by PE items was $20.2 \%$.

At 95\% confidence level, PE1 $(\mathrm{B}=.115, \mathrm{t}=5.624, \mathrm{p}=.000), \mathrm{PE} 2(\mathrm{~B}=$ $.068, \mathrm{t}=2.910, \mathrm{p}=.004)$, PE3 $(\mathrm{B}=.049, \mathrm{t}=2.362, \mathrm{p}=.018)$, PE4 $(\mathrm{B}=.056, \mathrm{t}=$ 2.566, $\mathrm{p}=.010)$, PE6 $(\mathrm{B}=.125, \mathrm{t}=6.245, \mathrm{p}=.000)$ and PE9 $(\mathrm{B}=.065, \mathrm{t}=2.773$, $\mathrm{p}=.006)$ were significant predictors of $\mathrm{CMa}$. On the contrary, it was found that PE5 ( $\mathrm{B}=-.010, \mathrm{t}=-.473, \mathrm{p}=.637)$, PE7 $(\mathrm{B}=.016, \mathrm{t}=.680, \mathrm{p}=.497)$, PE8 ( $\mathrm{B}=$ $-.017, \mathrm{t}=.680, \mathrm{p}=.497)$ and PE10 $(\mathrm{B}=.031, \mathrm{t}=1.630, \mathrm{p}=.103)$ were not significant predictors of CMa.

Personal Empowerment (PE) items account for 20.2\% of Proactive Participation (CMa). Seven (7) of PE items were significant predictors of CMa.

Table 6 Multiple Linear Regression - PE predicting CMb

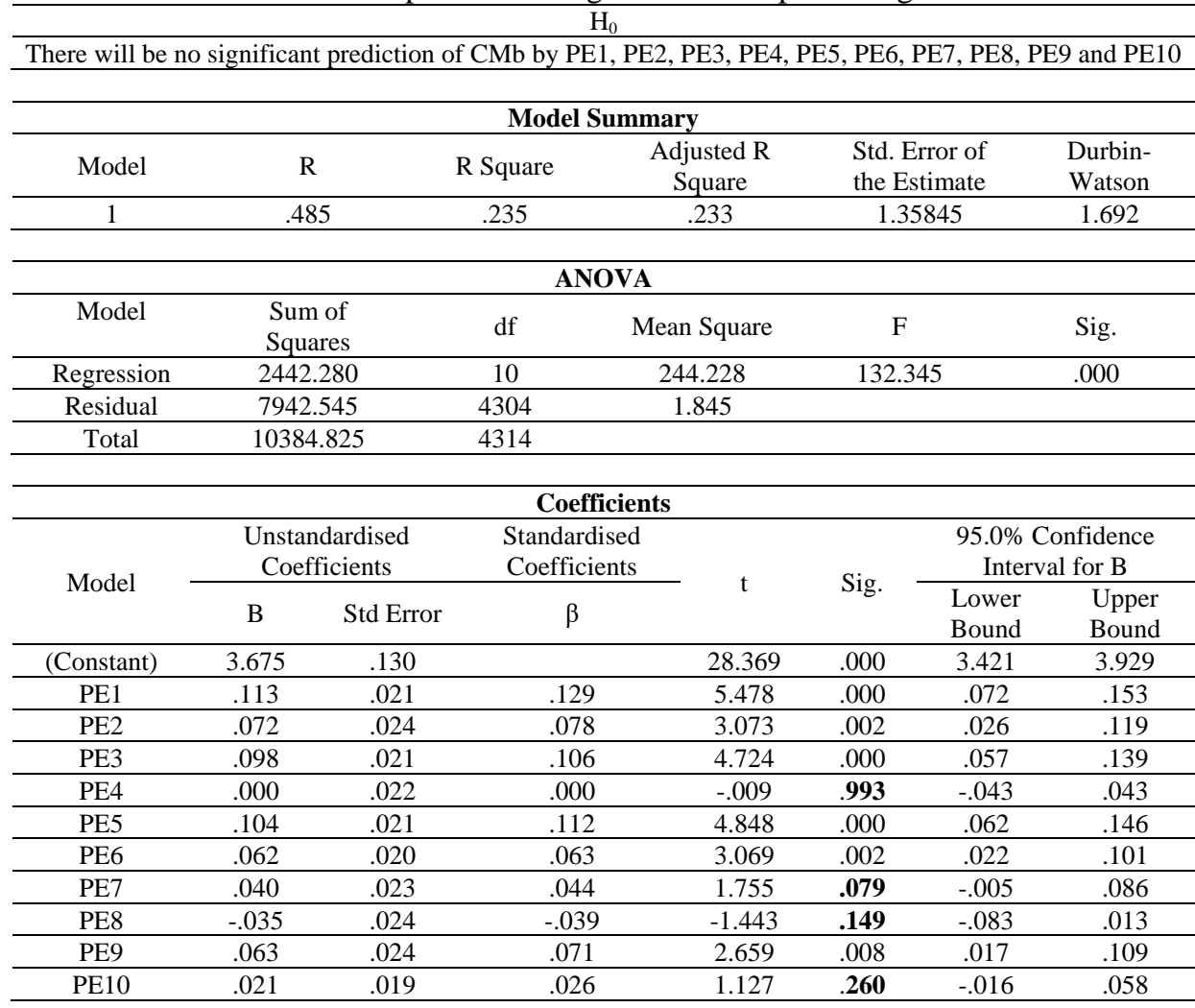

A multiple regression was generated to predict $\mathrm{CMb}$ based on PE items. $R$ value of .485 indicated a satisfactory level of prediction $(R>0.5)$. The DurbinWatson statistic was 1.692 which is between 1.5 and 2.5 and therefore the data was not autocorrelated. A significant regression equation was found, $F(10,4304)$ 
Aisyah Abu Bakar, Mariana Mohamed Osman \& Muhammad Faris Abdullah

Empowering Community Movement: Empirical Evidence

$=132.345, \mathrm{p}=.000$, with an $\mathrm{R}^{2}$ of .235 ; indicating that the proportion of variance in $\mathrm{CMb}$ that can be explained by PE items was $23.5 \%$.

At 95\% confidence level, PE1 $(\mathrm{B}=.113, \mathrm{t}=5.478, \mathrm{p}=.000)$, PE2 $(\mathrm{B}=$ $.072, \mathrm{t}=3.073, \mathrm{p}=.002) ;$, PE3 $(\mathrm{B}=.098, \mathrm{t}=4.724, \mathrm{p}=.000)$, PE5 $(\mathrm{B}=.104, \mathrm{t}=$ $4.848, \mathrm{p}=.000)$, PE6 $(\mathrm{B}=.062, \mathrm{t}=3.069, \mathrm{p}=.002)$ and PE9 $(\mathrm{B}=.063, \mathrm{t}=2.659$, $\mathrm{p}=.008$ ) were significant predictors of $\mathrm{CMb}$. On the contrary, it was found that PE4 ( $\mathrm{B}=.000, \mathrm{t}=-.009, \mathrm{p}=.993)$, PE7 ( $\mathrm{B}=.040, \mathrm{t}=1.755, \mathrm{p}=.075)$, PE8 ( $\mathrm{B}=$ $-.035, \mathrm{t}=-1.443, \mathrm{p}=.149)$ and PE10 $(\mathrm{B}=.021, \mathrm{t}=1.127, \mathrm{p}=.260)$ were not significant predictors of $\mathrm{CMb}$.

Personal Empowerment (PE) items account for $23.5 \%$ of Affability and Respect for Diversity (CMb). Six (6) of PE items were significant predictors of $\mathrm{CMb}$.

Table 7 Multiple Linear Regression - PE predicting CMc

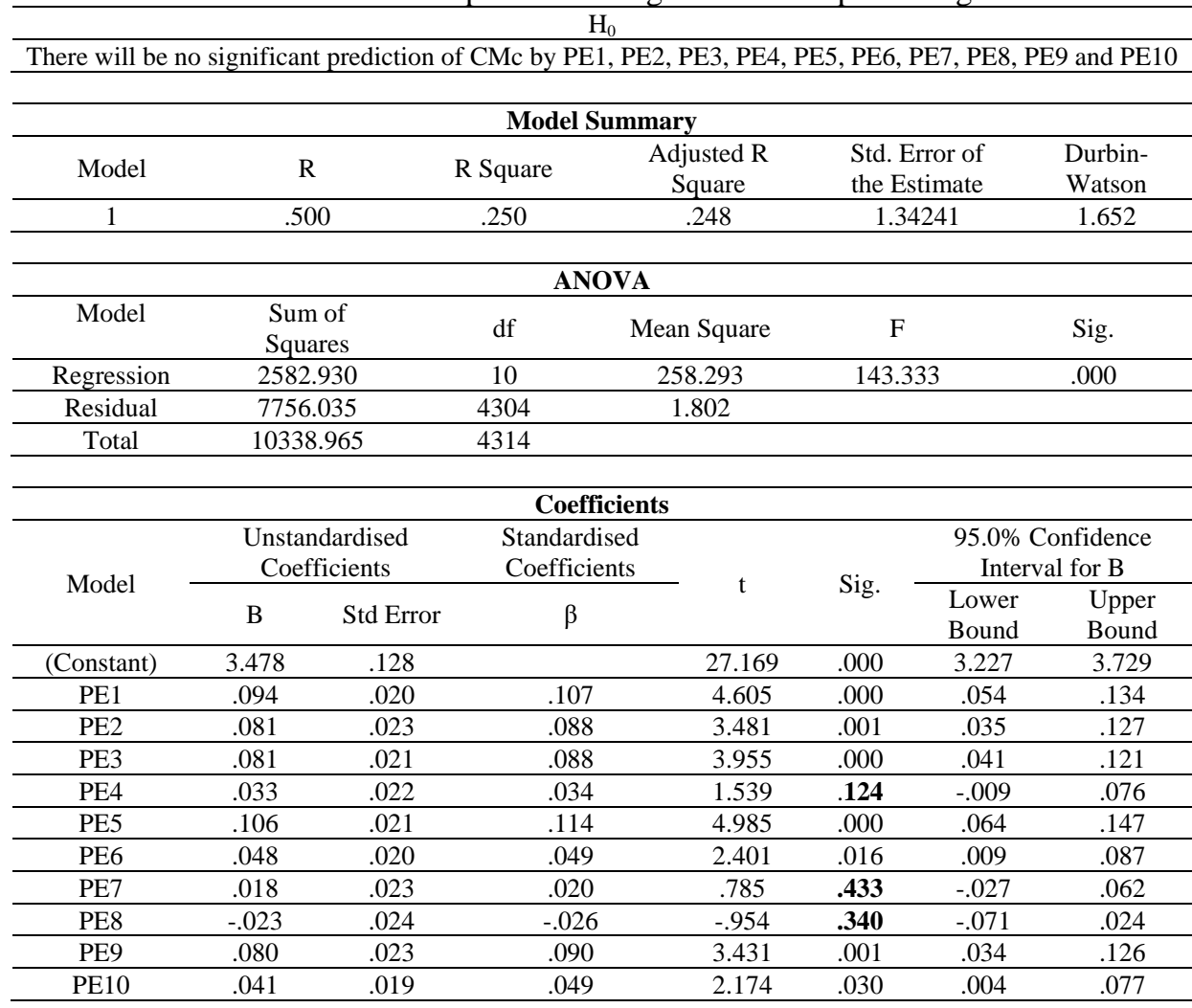

A multiple regression was generated to predict $\mathrm{CMc}$ based on PE items. $R$ value of .500 indicated an acceptable level of prediction $(R>0.5)$. The DurbinWatson statistic was 1.652 which is between 1.5 and 2.5 and therefore the data was not autocorrelated. A significant regression equation was found, $F(10,4304)$ 
$=143.333, \mathrm{p}=.000$, with an $\mathrm{R}^{2}$ of .250 ; indicating that the proportion of variance in CMc that can be explained by PE items was $25 \%$.

At 95\% confidence level, PE1 (B =.094, $\mathrm{t}=4.605, \mathrm{p}=.000), \mathrm{PE} 2(\mathrm{~B}=$ $.081, \mathrm{t}=3.481, \mathrm{p}=.001)$, PE3 $(\mathrm{B}=.081, \mathrm{t}=3.955, \mathrm{p}=.000)$, PE5 $(\mathrm{B}=.106, \mathrm{t}=$ $4.985, \mathrm{p}=.000)$, PE6 $(\mathrm{B}=.048, \mathrm{t}=2.401, \mathrm{p}=.016)$, PE9 $(\mathrm{B}=.080, \mathrm{t}=3.431, \mathrm{p}$ $=.001)$ and PE10 $(\mathrm{B}=.041, \mathrm{t}=2.174, \mathrm{p}=.030)$ were significant predictors of CMc. On the contrary, it was found that PE4 $(\mathrm{B}=.033, \mathrm{t}=1.539, \mathrm{p}=.124)$, PE7 $(\mathrm{B}=.018, \mathrm{t}=.785, \mathrm{p}=.433)$ and PE8 $(\mathrm{B}=-.023, \mathrm{t}=-.954, \mathrm{p}=.340)$ were not significant predictors of $\mathrm{CMc}$.

Personal Empowerment (PE) items account for 25\% of Belongingness $(\mathrm{CMc})$. Seven (7) of PE items were significant predictors of CMc.

Table 8 Summary of findings

\begin{tabular}{|c|c|c|c|c|}
\hline & & \multicolumn{3}{|c|}{ IV (Predictor Variables) - $\beta$} \\
\hline & & PE4 & PE5 & PE10 \\
\hline \multirow{3}{*}{$\begin{array}{c}\text { DV } \\
\text { (Outcome } \\
\text { Variables) } \\
\end{array}$} & $\mathrm{CMa}$ & $\begin{array}{cccccc}.135 & \mathbf{0 7 6} \checkmark & .054 \checkmark & .058 \checkmark & -.0\end{array}$ & $1 \times .131 \checkmark .017 \times-.020 \times .075 \checkmark$ & $.038 X$ \\
\hline & $\mathrm{CMb}$ & $.129 \checkmark \quad .078 \checkmark .106 \checkmark \quad .000 \times \quad .1$ & $112 \checkmark .063 \checkmark .044 \times-.039 \times .071 \checkmark$ & $.026 X$ \\
\hline & $\mathrm{CMc}$ & $\begin{array}{llllll}. \mathbf{1 0 7} \checkmark & .088 \checkmark & \mathbf{0 8 8} \checkmark & .034 \times \mathbf{. 1}\end{array}$ & $.114 \checkmark \quad .049 \checkmark \quad .020 \times-.026 \times .090 \checkmark$ & $.049 \checkmark$ \\
\hline \multicolumn{5}{|c|}{$\checkmark=$ statistically significant predictor; $\boldsymbol{X}=$ not statistically significant predictor } \\
\hline & \multicolumn{2}{|c|}{ Indicators } & IV Top 3 Strongest Pred & $\beta$ \\
\hline \multirow{3}{*}{$\begin{array}{c}\text { CMa } \\
\text { Proactive } \\
\text { Participation }\end{array}$} & \multirow{3}{*}{\multicolumn{2}{|c|}{$\begin{array}{l}\text { - conscious of new updates } \\
\text { - participating enthusiastically in organized } \\
\text { activities } \\
\text { - assuming responsibility when foreseeing } \\
\text { community issues }\end{array}$}} & $\begin{array}{l}\text { PE1 } \begin{array}{l}\text { setting goals and striving to meet } \\
\text { goals }\end{array}\end{array}$ & .135 \\
\hline & & & $\begin{array}{l}\text { PE6 able to be friendly with distasteful } \\
\text { persons when necessary }\end{array}$ & .131 \\
\hline & & & $\begin{array}{l}\text { PE2 striving and working hard even for } \\
\text { easy goals }\end{array}$ & .076 \\
\hline \multirow{3}{*}{$\begin{array}{c}\text { CMb } \\
\text { Affability } \\
\text { and Respect } \\
\text { for Diversity }\end{array}$} & \multirow{3}{*}{\multicolumn{2}{|c|}{$\begin{array}{l}\text { - approachable to people of different } \\
\text { ethnicity and religion } \\
\text { - approachable to people of different ranks } \\
\text { and status } \\
\text { - enjoying social interaction with community } \\
\text { - adapting and adjusting fast to new social } \\
\text { environment }\end{array}$}} & $\begin{array}{l}\text { PE1 } \begin{array}{l}\text { setting goals and striving to meet } \\
\text { goals }\end{array} \\
\end{array}$ & .129 \\
\hline & & & $\begin{array}{l}\text { PE5 ensuring others are comfortable } \\
\text { when making deals }\end{array}$ & .112 \\
\hline & & & $\begin{array}{l}\text { PE3 } \begin{array}{l}\text { monitoring behaviours to suit with } \\
\text { situations }\end{array} \\
\end{array}$ & .106 \\
\hline \multirow{3}{*}{$\begin{array}{c}\text { CMc } \\
\text { Belonging- } \\
\text { ness }\end{array}$} & \multirow{3}{*}{\multicolumn{2}{|c|}{$\begin{array}{l}\text { - ability to influence shared decisions } \\
\text { - offering assistance voluntarily when } \\
\text { necessary } \\
\text { - feeling sense of belonging with the } \\
\text { community }\end{array}$}} & $\begin{array}{l}\text { PE5 ensuring others are comfortable } \\
\text { when making deals }\end{array}$ & .114 \\
\hline & & & PE1 $\begin{array}{l}\text { setting goals and striving to meet } \\
\text { goals }\end{array}$ & .107 \\
\hline & & & $\begin{array}{l}\text { PE3 lonitoring behaviours to suit with } \\
\text { situations }\end{array}$ & .088 \\
\hline
\end{tabular}

The empirical evidence reveals that the majority of PE items significantly account for $\mathrm{CMa}, \mathrm{CMb}$ and $\mathrm{CMc}$. PE1 which stand for 'setting goals and striving to meet goals' was in the top three strongest predictors for all components of CM - thus suggesting that community members' goal setting and commitment to attain those goals are the key to community advancement. Goal setting calls for inspiration, while commitment requires concentration and sense of dedication. Designs strategies that exhibit respect to local history and regional character, 
Aisyah Abu Bakar, Mariana Mohamed Osman \& Muhammad Faris Abdullah

Empowering Community Movement: Empirical Evidence

well-designed and -maintained civic buildings, as well as mixed land uses to allow various activities can revitalise communal happenings and promotes a sense of belongingness. Such conducive neighbourhoods empower community members to restore social and economic fabric leading to positive community movement.

\section{CONCLUSION}

$\mathrm{HIH}$ in SSWB accounts for personal development in relation to the surrounding context. This paper proves that community movement is a significant outcome of personal empowerment. The results warrant for further tests on the constructs explained in this paper.

\section{REFERENCES}

Ahmad Marzuki, N., Azizah Ahmad, N., Shukri Abdul Hamid, A., Sobhi Ishak, M., Marzuki, N. A., Ahmad, N. A., ... Ishak, M. S. (2014). Community social capital in Malaysia: A pilot study. Asian Social Science, 10(12), 202-209.

Chin, N.-S., Khoo, S., \& Low, W.-Y. (2012). Self-determination and goal orientation in track and field. Journal of Human Kinetics, 33(1), 151-161.

Chong, S. T., Ten, W. K., Er, A. C., \& Koh, D. (2013). Neighbourhood participation as a proxy to civic engagement. Pertanika Journal of Social Science and Humanities, $21(\mathrm{~S}), 143-154$.

Dancey, C., \& Reidy, J. (2004) Statistics without maths for psychology: Ssing SPSS for Windows. London: Prentice Hall.

Hamdan, H., Yusof, F., \& Marzukhi, M. A. (2014). Social capital and quality of life in urban neighborhoods high density housing. Procedia - Social and Behavioral Sciences, 153, 169-179.

Ibrahim, R., \& Hamid, T. A. (2014). Social embeddedness as a mechanism for linking social cohesion to well-being among older adults: Moderating effect of gender. Clinical Interventions in Aging, 9, 863-870.

Kadir, N. B. A., Omar, F., Desa, A., \& Yusooff, F. (2013). Secure style, PWB-related gratitude and SWB-related engagement as predictors of affect balance among social science students in Malaysia: A pilot study. Pertanika Journal of Social Science and Humanities, 21, 85-98.

Kok, J. K. (2016). The relationships between procrastination and motivational aspects of self-regulation. Jurnal Psikologi Malaysia, 30(1), 30-39.

Lino, M., Hashim, I. H. M., \& Ricardo, R. (2017). The lurking racism: Exploring racial microaggression in the Malaysian university setting. Pertanika Journal of Social Science and Humanities, 25(1), 473-484.

Mahadi, Z., \& Sino, H. (2013). Defining public needs in sustainable development: A case study of Sepang, Malaysia. Pertanika Journal of Social Science and Humanities, 2l(4), 1341-1360.

Nawaz, F. (2017). Strengthening women through group participation, trust and networks : A study on women's self-help groups in Bangladesh. Pertanika Journal of Social Science and Humanities, 25(1), 45-60.

Nesbit, P. L., Jepsen, D., Demirian, S., \& Ho, J. (2012). Extending self-leadership research to the East: Measurement equivalence of the Chinese and English versions of the MSLQ. Asian Journal of Social Psychology, 15(2), 101-111. 
Rahyla, S. (2017). The local people perceptions on the economic impacts of indonesian workers in rural areas: A case study at Rural Johor. Pertanika Journal of Social Science and Humanities, 25(1), 485-502.

Sipon, S., Nasrah, S. K., Nazli, N. N. N. N., Abdullah, S., \& Othman, K. (2014). Stress and religious coping among flood victims. Procedia - Social and Behavioral Sciences, 140, 605-608.

Sulaiman, W. S. W., Kadir, N. B. A., Halim, F. W., Omar, F., Latiff, R. A., \& Sulaiman, W. S. W. (2013). Structural relations between personality traits, coping strategy, social support and well-being among adolescents. Pertanika Journal of Social Science and Humanities, 21 (December), 121-134.

Thomas, V. B., Selvadurai, S., Er, A. C., Lyndon, N., \& Moorthy, R. (2011). Factors Influencing Commitment of Volunteers' in Neighborhood Watch Organization. Journal of Social Sciences, 7(4), 569-574.

Tunku, U., Rahman, A., \& Campus, P. (2017). Youth engagement in meaningful activities and happiness: A comparative study of Chinese undergraduates from Taiwan and Malaysia. Pertanika Journal of Social Science and Humanities, 25(1), 445-460.

Yassin, S. M., Dahalan, D., Abdullah, H., Ismail, I. A., Hamzah, A., Ahmad, N., ...\& Serit, B. (2013). Challenges in the social environment landscape: Readiness of youth in embracing diversity. Pertanika Journal of Social Science and Humanities, 21(July), 11-20.

Zamani, Z. A., Khairudin, R., Sulaiman, W. S. W., Halim, F. W., \& Nasir, R. (2013). Relationship between achievement motivation and personality among pre and post-independence Malaysian Malays. Pertanika Journal of Social Science and Humanities, 21(December), 135-142

Received: $12^{\text {th }}$ January 2019. Accepted: $2^{\text {nd }}$ August 2019 